
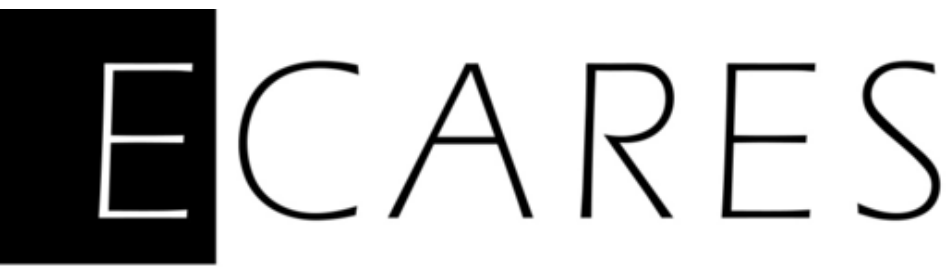

Governance Choices and Policy Outcomes in the Latin American and Caribbean Electricity Sector

\author{
Morgane de Halleux \\ SBS-EM, ECARES, Université libre de Bruxelles \\ Antonio Estache \\ SBS-EM, ECARES, Université libre de Bruxelles \\ Tomas Serebrisky \\ Inter-American Development Bank
}

January 2019

ECARES working paper 2019-08

ECARES

ULB - CP 114/04

50, F.D. Roosevelt Ave., B-1050 Brussels BELGIUM

www.ecares.org 


\title{
Governance choices and policy outcomes in the Latin American and Caribbean electricity sector ${ }^{1}$
}

\author{
Morgane de Halleux \\ (Université Libre de Bruxelles) \\ Antonio Estache \\ (ECARES, Université Libre de Bruxelles) \\ Tomas Serebrisky \\ (Inter-American Development Bank)
}

\begin{abstract}
The paper first provides for Latin America and the Caribbean, country specific synthetic quantitative measures of the degree of adoption of common governance reforms of the electricity sector accounting for four key dimensions (market structure, private sector participation, regulatory autonomy and operational organization). These synthetic indicators are then correlated with standard policy performance outcomes measures. This suggests that, as of 2018, reforms could be statistically significantly associated with higher technical quality but not with social or service improvements. This implies that almost 30 years after their adoption and despite recurring reports of failures in these three decades, governance reforms are still not delivering on some promised payoffs, notably the reduction of the energy poverty issues.
\end{abstract}

\footnotetext{
${ }^{1}$ This document is a product of the research program developed for the preparation of the Inter-American Development Bank 2020 flagship report Infrastructure Services in Latin America. All of the background papers of the research program are available at www.iadb.org/infrastructureservices. The authors are grateful for discussions and comments from Salvador Bertomeu-Sanchez, Richard Schlirf, and Fransesc Trillas. Any mistakes or misinterpretations are the sole responsibility of the authors and should not be attributed to any of the institutions with which they are affiliated.
} 


\section{Introduction}

The Latin America and the Caribbean region (LAC) has recently been working on a new wave of governance reforms of its electricity sector to improve its supply side by increasing the role of smart-grid technologies, distributed generation, and other technological innovations. As these changes are being rolled out, it seems useful to take stock of the outcomes of earlier governance reforms on both the supply and the demand sides of the sector. This could help define the baseline needed to assess the impact of the new reform wave. It could also identify obvious gaps in the changes under way or under consideration, including undelivered promises of older reforms.

To do so, the paper matches specific achievements on common concerns in policy debates and specific governance characteristics at the country level in a comparable way across countries. The match is anchored in a new set of synthetic composite indicators that account for the multiplicity of dimensions of governance and outcomes as well as for the economic heterogeneity of the countries of the region. The most basic analysis of the relevance of governance allowed by these indicators already highlights a wide range of insights consistent with those identified by Jasmab et al. (2017) in their review of the international experience with electricity reforms but it is not precise or robust enough.

How much governance actually matters, which governance dimensions and how they matter continues to be debated in policy and academic circles. These questions thus beg for additional research as suggested by Bensch et al (2016) in their own survey. Part of the lack of certainty on the sign and strength of the interactions between governance and performance outcomes is linked to the fact that many diagnostics focus on a single dimension of governance (e.g. privatization) and/or one performance outcome (e.g. investment). Even if the assessment of these marginal effects is obviously useful, they can be misleading since governance is best characterized by a package of institutional characteristics and expected outcomes are typically multidimensional. In other words, cherry picking a specific dimensions or outcome can bias the big picture on the impact of reforms.

To address this diversity of both governance and outcomes dimensions, we proceed as follows. For governance, we focus on four specific dimensions, namely, (a) market structure (unbundled or not), (b) opening to private sector participation, (c) the creation (or not) of a separate regulatory agency, and (d) the introduction of competition in the sector, which we then aggregate into a single reform adoption measure. From this characterization of governance reforms, we find that, as of 2018, reforms could globally be statistically significantly and robustly directly correlated with higher technical quality but not with social or service improvements. In other words, the reforms delivered more on the supply side than on the demand side of the sector. In relative terms, the creation of regulatory institutions is the only one of the reforms with a strong correlation with at least three of the policy goals. The other reforms could at best be weakly correlated with only one of the outcomes.

For outcomes, we take stock of the various dimensions identified in the literature summarized by Jasmab et al (2017) to get a reasonably exhaustive diagnostic. We also rely on three widely quoted papers which have already focused on the impact of governance reforms in the region in the 10 to 15 years that followed the initial waves of changes in the late 1990s to mid=2000s (Andres et al. (2008); Andres et al. (2013); and Balza et al. (2013)). And we follow the recurring 
case made by a growing number of authors to account for multiple outcomes when assessing reforms.. ${ }^{2}$

The three papers focusing on LAC consider a range of governance changes similar to those we track here (e.g., unbundling, privatization, regulation), but they do not fully account for the interactions between these changes. They all largely confirm for the region the conclusion reached by Jasmab et al. (2017) on the global experience. They find, for example, that privatization was associated with improvements in quality and efficiency in the region but not with better access to service. Their results also show that regulatory and institutional quality can matter to outcomes regardless of the level of private participation. But they don't provide an integrated picture of the relative importance of the various reforms, of their interactions and of the way these matter to the outcomes.

Accounting for the joint effects of related governance reforms, rather than assessing the effect of each of them individually, it is needed to get a better appreciation of the complementarity of the main institutional changes countries adopt within subgroups of reform. Given the modest size of the data sample available, getting meaningful insights is not possible using standard econometric approaches. One way of dealing with this limitation is to rely on more basic statistical treatment of the data and this is the approach adopted here.

For each country, related governance dimensions are translated into a single indicator "grading" the changes adopted on a scale of 0-100. Using this scale, we rank 33 of LAC's countries in terms of their level of adoption of the reforms typically considered desirable during the 1990s reform waves. ${ }^{3}$ This provides an encompassing sense of how far individual countries have moved away from the historical vertically integrated public monopoly that was the global norm in the electricity sector until the 1990s and makes it relatively easy to correlate reforms with specific policy outcomes. We produce similar indicators for the usual broad categories of policy concern (access, affordability, technical quality and service quality).

The aggregate synthetic governance indicator proposed here refines the indicator recently produced by the World Bank for 88 developing countries (including 14 in LAC) analyzed by Foster et al. (2017). Their indicator also synthesizes the four dimensions of power sector reform with a focus on the degree of unbundling, the existence of an autonomous regulatory entity, the entry of private management and capital, and the extent to which generators are allowed to compete to supply a monopoly utility and customers to negotiate their supply contracts. ${ }^{4}$ However, their indicator assigns equal weights to all dimensions. This ignores the relevance of possible correlation across indicators and hence of the differences in the relative importance of the various reform groups and of their interactions. This is a significant weakness as noted by Polemis (2016) since it can lead to over or underestimating the impact of specific sets of reforms. To correct this, we rely on a weighting procedure that accounts explicitly for interactions among

\footnotetext{
${ }^{2}$ Andres, Schwartz, and Guasch (2013) focus on electricity distribution, working with data at the firm level in 26 countries for the 1995-2005 period. Balza, Jimenez, and Mercado (2013) work with sector-level data at the country level. Their study covers 18 countries for the 1971-2010 period.

${ }^{3}$ This exercise says nothing about the desirability of these reforms.

${ }^{4}$ Foster et al. (2017) then use the indicators to measure the extent to which the reform choices were influenced by country characteristics, such as geography, income group, power system size, and political economy, but do not look at outcomes.
} 
dimensions.

The rest of the paper is organized as follows. Section 2 presents the methodology. Section 3 discusses the results. Section 4 reports the correlation between the index of electricity reforms and the different aspects of quality of the service delivered. Section 5 summarizes the paper's main conclusions.

\section{The creation a composite index of electricity reforms}

The development of the index can be described in four steps. The process starts with the identification of a coherent set of indicators used to characterize the sector from an institutional perspective and emphasizing the main dimensions typically considered in discussions of reforms of the sector. Next is the description of the way we turned the institutional description into quantitative measures. The third step explains how we normalize the data for each governance dimension of interest to prepare the creation of the synthetic indexes. Finally, we discuss how the normalized data is used to produce the index. The details are as follows:

\section{Step 1: Identification of the Indicators}

Based on the survey of the literature, we identified eight indicators capturing the main governance dimensions typically discussed in the context of electricity reforms:

i. degree of competition in electricity transmission

ii. degree of vertical integration (which reflects the range of integration over all industry functions)

iii. participation of the private sector in generation, transmission, and distribution

iv. existence of a separate regulatory entity

v. experience of the regulatory agency (approximated by the number of years it has been in place since its creation)

vi. existence of a transmission system operator

vii. $\quad$ existence of an independent system operator

viii. existence of a wholesale market operator.

To structure the discussion in broad governance dimensions, we regroup the indicators into four separate dimensions commonly mentioned in policy discussions:

- $\quad$ market structure $(\mathrm{i}+\mathrm{ii})$

- private sector participation (iii)

- regulatory autonomy and experience $(\mathrm{iv}+\mathrm{v})$

- operational organization (vi + vii + viii).

\section{Step 2: Data Collection}

As in most policy diagnostics, data collection proved to be one of the most frustrating parts of the evaluation process. Despite almost 30 years of reforms experiences in the region, data remains a challenge. There is still only limited comparability of information across countries, and most databases are either not open access and/or include only limited coverage of smaller economies. This suggests that the international community still does not take measurement seriously enough except for very broad indicators which are not detailed enough to be able to conduct precise reform impact evaluations. 
The choice of indicators was thus limited by the availability of comparable data for a large number of economies. We opted to focus on the indicators that allowed us to maximize the number of economies covered. We managed to collect comparable data for 33 countries in LAC (including Puerto Rico but not Cuba because of lack of available information). Most of the data are for 2018, unless it was unavailable, in which case we used the latest data available which could be for as far back as 2015. The raw information collected from multiple sources and interactions with field specialists working in the region is synthetized in Table 1.

\section{Step 3: Normalization of the Data to Produce a Synthetic Index}

The composite index created to aggregate the information on the governance categories characterized by at least 2 dimensions is expressed as

$$
I=\sum_{i=1}^{n} w_{i} x_{i}
$$

where $I$ is the composite index; $x_{i}$ is the normalized variable; $w_{i}$ is the weight of the $x_{i}$, $\sum_{i=1}^{n} w_{i}=1,0 \leq w_{i} \leq 1$; and $i=1, \ldots, n$.

The index is quite simple but cannot be used with the raw data reported in Table 1 since the variables have different measurement units and therefore cannot be aggregated. To eliminate the bias of scale in the calculation of the composite indicator, we standardize the raw data. We report the new dataset in Table 2 but to get to this set of normalized data, the following additional data manipulations were needed since some of the data is qualitative.

The indicators with qualitative values are turned into quantitative ones as follows:

- For the level of competition, monopoly, retail market competition, and wholesale market competition take the values of 0,1 , and 2 , respectively.

- For the level of unbundling, vertically integrated, partially vertically unbundled, and fully vertically unbundled take the values of 0,1 , and 2 , respectively.

- For the year of creation, we transformed the variable $x_{c}$ into $x^{\prime}{ }_{c}=2018-x_{c}$, where $x^{\prime}{ }_{c}$ is the new value of the indicator for country $c$ and $x_{c}$ is the year of creation of the regulator for the country $\mathrm{c}$. If the country does not have a regulator, the variable takes the value of 0 .

- To eliminate the bias of scale and be able to read all variables in the same direction, we normalized the data using the max-min method, transforming each indicator $q$ for city $c$ as follows:

$$
\text { - } I_{q c}=\frac{x_{q c}-\min \left(x_{q}\right)}{\max \left(x_{q}\right)-\min \left(x_{q}\right)},
$$

- where $\min \left(x_{q}\right)$ and $\max \left(x_{q}\right)$ are the minimum and maximum values of $x_{q}$ across all countries. The original normalized indicator $I_{q c}$ has values lying between $0\left(\min \left(x_{q}\right)\right)$ and $1\left(\max \left(x_{q}\right)\right)$ but we reset it to range from 0 to 100 for ease of reading and avoid excessive numbers of decimals. 


\begin{tabular}{|c|c|c|c|c|c|c|c|c|c|c|}
\hline \multirow{3}{*}{$\begin{array}{c}\text { Dimension } \\
\\
\text { Indicator }\end{array}$} & \multicolumn{2}{|c|}{ Market structure } & \multirow{2}{*}{\multicolumn{3}{|c|}{$\begin{array}{c}\text { Private sector participation } \\
\text { Separate }\end{array}$}} & \multicolumn{2}{|c|}{$\begin{array}{c}\text { Regulatory autonomy and } \\
\text { experience }\end{array}$} & \multicolumn{3}{|c|}{ Operational organization } \\
\hline & \multirow[b]{2}{*}{ Level of competition } & \multirow[b]{2}{*}{$\begin{array}{c}\text { Level of } \\
\text { unbundling }\end{array}$} & & & & \multirow{2}{*}{$\begin{array}{l}\text { Separate } \\
\text { regulator }\end{array}$} & \multirow[b]{2}{*}{$\begin{array}{l}\text { Year of } \\
\text { creation }\end{array}$} & \multirow{2}{*}{$\begin{array}{l}\text { Transmission } \\
\text { system } \\
\text { operator }\end{array}$} & \multirow{2}{*}{$\begin{array}{l}\text { Independent } \\
\text { system } \\
\text { operator }\end{array}$} & \multirow{2}{*}{$\begin{array}{c}\text { Wholesale } \\
\text { market } \\
\text { operator }\end{array}$} \\
\hline & & & $\begin{array}{l}\text { Gener- } \\
\text { ation }\end{array}$ & $\begin{array}{l}\text { Transmi- } \\
\text { ssion }\end{array}$ & $\begin{array}{l}\text { Distri- } \\
\text { bution }\end{array}$ & & & & & \\
\hline $\begin{array}{l}\text { Antigua and } \\
\text { Barbuda }\end{array}$ & Monopoly & $\begin{array}{l}\text { Vertically } \\
\text { integrated }\end{array}$ & Yes & No & No & No & 1973 & No & No & No \\
\hline Argentina & $\begin{array}{l}\text { Retail market } \\
\text { competition }\end{array}$ & $\begin{array}{c}\text { Fully } \\
\text { vertically } \\
\text { unbundled }\end{array}$ & Yes & Yes & Yes & Yes & 1992 & No & Yes & Yes \\
\hline Bahamas & Monopoly & $\begin{array}{l}\text { Vertically } \\
\text { integrated }\end{array}$ & Yes & Yes & Yes & Yes & 2009 & No & No & No \\
\hline Barbados & Monopoly & $\begin{array}{l}\text { Vertically } \\
\text { integrated }\end{array}$ & Yes & Yes & Yes & Yes & 2001 & No & No & Yes \\
\hline Belize & $\begin{array}{l}\text { Retail market } \\
\text { competition }\end{array}$ & $\begin{array}{c}\text { Partially } \\
\text { vertically } \\
\text { unbundled }\end{array}$ & Yes & Yes & Yes & Yes & 1999 & No & No & No \\
\hline Bolivia & $\begin{array}{l}\text { Retail market } \\
\text { competition }\end{array}$ & $\begin{array}{c}\text { Fully } \\
\text { vertically } \\
\text { unbundled }\end{array}$ & Yes & Yes & Yes & Yes & 1994 & Yes & Yes & Yes \\
\hline Brazil & $\begin{array}{l}\text { Wholesale } \\
\text { competition }\end{array}$ & $\begin{array}{c}\text { Fully } \\
\text { vertically } \\
\text { unbundled }\end{array}$ & Yes & Yes & Yes & Yes & 1996 & Yes & Yes & Yes \\
\hline Chile & $\begin{array}{l}\text { Retail market } \\
\text { competition }\end{array}$ & $\begin{array}{c}\text { Fully } \\
\text { vertically } \\
\text { unbundled }\end{array}$ & Yes & Yes & Yes & Yes & 1978 & No & Yes & Yes \\
\hline Colombia & $\begin{array}{l}\text { Wholesale } \\
\text { competition }\end{array}$ & $\begin{array}{c}\text { Partially } \\
\text { vertically } \\
\text { unbundled }\end{array}$ & Yes & Yes & Yes & Yes & 1992 & No & Yes & Yes \\
\hline Costa Rica & Monopoly & $\begin{array}{l}\text { Vertically } \\
\text { integrated }\end{array}$ & Yes & No & No & Yes & 1996 & No & No & Yes \\
\hline Dominica & $\begin{array}{l}\text { Retail market } \\
\text { competition }\end{array}$ & $\begin{array}{l}\text { Vertically } \\
\text { integrated }\end{array}$ & Yes & Yes & Yes & Yes & 2006 & No & No & No \\
\hline $\begin{array}{l}\text { Dominican } \\
\text { Republic }\end{array}$ & $\begin{array}{l}\text { Wholesale } \\
\text { competition }\end{array}$ & $\begin{array}{c}\text { Fully } \\
\text { vertically } \\
\text { unbundled }\end{array}$ & Yes & No & No & Yes & 1998 & Yes & Yes & Yes \\
\hline Ecuador & $\begin{array}{l}\text { Wholesale } \\
\text { competition }\end{array}$ & $\begin{array}{c}\text { Fully } \\
\text { vertically } \\
\text { unbundled }\end{array}$ & Yes & No & No & Yes & 1998 & No & Yes & Yes \\
\hline El Salvador & $\begin{array}{c}\text { Retail market } \\
\text { competition }\end{array}$ & $\begin{array}{c}\text { Fully } \\
\text { vertically } \\
\text { unbundled } \\
\end{array}$ & Yes & No & Yes & Yes & 1997 & Yes & Yes & Yes \\
\hline Guatemala & $\begin{array}{l}\text { Wholesale } \\
\text { competition }\end{array}$ & $\begin{array}{c}\text { Fully } \\
\text { vertically } \\
\text { unbundled }\end{array}$ & Yes & Yes & Yes & No & 1996 & No & Yes & Yes \\
\hline Guyana & Monopoly & $\begin{array}{l}\text { Vertically } \\
\text { integrated }\end{array}$ & Yes & No & No & Yes & 1999 & No & No & No \\
\hline Grenada & Monopoly & $\begin{array}{l}\text { Vertically } \\
\text { integrated }\end{array}$ & Yes & Yes & Yes & No & - & No & No & No \\
\hline Haiti & $\begin{array}{l}\text { Retail market } \\
\text { competition }\end{array}$ & $\begin{array}{l}\text { Vertically } \\
\text { integrated }\end{array}$ & Yes & Yes & Yes & No & - & No & No & No \\
\hline Honduras & $\begin{array}{l}\text { Retail market } \\
\text { competition }\end{array}$ & $\begin{array}{l}\text { Vertically } \\
\text { integrated }\end{array}$ & Yes & No & No & Yes & 1995 & No & No & Yes \\
\hline Jamaica & $\begin{array}{l}\text { Retail market } \\
\text { competition }\end{array}$ & $\begin{array}{l}\text { Vertically } \\
\text { integrated }\end{array}$ & Yes & Yes & Yes & Yes & 1995 & No & No & No \\
\hline Mexico & $\begin{array}{c}\text { Wholesale } \\
\text { competition }\end{array}$ & $\begin{array}{l}\text { Vertically } \\
\text { integrated }\end{array}$ & Yes & No & No & Yes & 1995 & No & Yes & Yes \\
\hline Nicaragua & $\begin{array}{l}\text { Wholesale } \\
\text { competition }\end{array}$ & $\begin{array}{c}\text { Fully } \\
\text { vertically } \\
\text { unbundled }\end{array}$ & Yes & No & Yes & Yes & 1979 & No & No & Yes \\
\hline Panama & $\begin{array}{c}\text { Wholesale } \\
\text { competition }\end{array}$ & $\begin{array}{l}\text { Vertically } \\
\text { integrated }\end{array}$ & Yes & No & Yes & Yes & 2006 & No & Yes & Yes \\
\hline Paraguay & Monopoly & $\begin{array}{l}\text { Vertically } \\
\text { integrated }\end{array}$ & No & No & No & No & - & No & No & No \\
\hline Peru & $\begin{array}{l}\text { Wholesale } \\
\text { competition }\end{array}$ & $\begin{array}{c}\text { Fully } \\
\text { vertically } \\
\text { unbundled }\end{array}$ & Yes & Yes & Yes & Yes & 1996 & No & Yes & Yes \\
\hline Puerto Rico & $\begin{array}{l}\text { Retail market } \\
\text { competition }\end{array}$ & $\begin{array}{l}\text { Vertically } \\
\text { integrated }\end{array}$ & Yes & Yes & Yes & Yes & 2014 & No & No & No \\
\hline $\begin{array}{l}\text { St. Kitts and } \\
\text { Nevis }\end{array}$ & Monopoly & $\begin{array}{l}\text { Vertically } \\
\text { integrated }\end{array}$ & Yes & Yes & Yes & No & - & No & No & No \\
\hline St. Lucia & Monopoly & $\begin{array}{l}\text { Vertically } \\
\text { integrated }\end{array}$ & Yes & Yes & Yes & Yes & 1964 & No & No & No \\
\hline $\begin{array}{l}\text { St. Vincent and } \\
\text { the Grenadines }\end{array}$ & Monopoly & $\begin{array}{l}\text { Vertically } \\
\text { integrated }\end{array}$ & Yes & Yes & Yes & No & - & No & No & No \\
\hline Suriname & $\begin{array}{c}\text { Retail market } \\
\text { competition }\end{array}$ & $\begin{array}{c}\text { Fully } \\
\text { vertically } \\
\text { unbundled }\end{array}$ & Yes & No & Yes & No & - & Yes & Yes & Yes \\
\hline $\begin{array}{l}\text { Trinidad and } \\
\text { Tobago } \\
\end{array}$ & Monopoly & $\begin{array}{l}\text { Vertically } \\
\text { integrated }\end{array}$ & Yes & No & No & Yes & 1966 & No & No & No \\
\hline Uruguay & $\begin{array}{l}\text { Retail market } \\
\text { competition }\end{array}$ & $\begin{array}{l}\text { Vertically } \\
\text { integrated }\end{array}$ & Yes & No & No & Yes & 1997 & No & No & No \\
\hline Venezuela, RB & Monopoly & $\begin{array}{l}\text { Vertically } \\
\text { integrated }\end{array}$ & No & No & No & No & 1992 & No & No & No \\
\hline
\end{tabular}


The approach has the advantage of being simple, but it has limitations. The main one may be that the range of values is sensitive to the choice of countries. If any country performs poorly on an indicator and/or another performs every well, these values will be distorted. This is why the specific values have to be interpreted cautiously and various sensitivity analysis may be needed when detailed country policy assessments are needed. In that context, the relative ranking produced by the approach should be used as a first order benchmarking approximation to be used to justify more in-depth performance diagnostics. For now, we will focus on the aggregate and average results of the normalization process as reported in Table 2 to get a sense of how widespread reform adoptions have been so far. The next step is to aggregate this information to refine the benchmarking first around specific reform dimensions and then across dimensions to get a full sense of the intensity of reform adoption in the region.

Table 2: Normalized values of electricity reforms in Latin America and the Caribbean, by economy (percent)

\begin{tabular}{|c|c|c|c|c|c|c|c|c|}
\hline Dimension & Marke & ructure & & $\begin{array}{r}\text { Regulator } \\
\text { ex }\end{array}$ & $\begin{array}{l}\text { tonomy and } \\
\text { ence }\end{array}$ & Ope & onal organiza & \\
\hline Economy & $\begin{array}{l}\text { Level of } \\
\text { competition }\end{array}$ & $\begin{array}{c}\text { Level of } \\
\text { unbundling }\end{array}$ & $\begin{array}{l}\text { Private sector } \\
\text { participation }\end{array}$ & $\begin{array}{l}\text { Separate } \\
\text { energy } \\
\text { regulator }\end{array}$ & $\begin{array}{l}\text { Year of } \\
\text { creation of } \\
\text { regulator }\end{array}$ & $\begin{array}{c}\text { Transmission } \\
\text { system } \\
\text { operator }\end{array}$ & $\begin{array}{c}\text { Independent } \\
\text { system } \\
\text { operator }\end{array}$ & $\begin{array}{c}\text { Wholesale } \\
\text { market } \\
\text { operator }\end{array}$ \\
\hline $\begin{array}{l}\text { Antigua and } \\
\text { Barbuda }\end{array}$ & 0 & 0 & 33.3 & 0 & 83.3 & 0 & 0 & 0 \\
\hline Argentina & 50 & 100 & 100 & 100 & 48.1 & 0 & 100 & 100 \\
\hline Bahamas, The & 0 & 0 & 100 & 100 & 16.7 & 0 & 0 & 0 \\
\hline Barbados & 0 & 0 & 100 & 100 & 31.5 & 0 & 0 & 100 \\
\hline Belize & 50 & 50 & 100 & 100 & 35.2 & 0 & 0 & 0 \\
\hline Bolivia & 50 & 100 & 100 & 100 & 44.4 & 100 & 100 & 100 \\
\hline Brazil & 100 & 100 & 100 & 100 & 40.7 & 100 & 100 & 100 \\
\hline Chile & 50 & 100 & 100 & 100 & 74.1 & 0 & 100 & 100 \\
\hline Colombia & 100 & 50 & 100 & 100 & 48.1 & 0 & 100 & 100 \\
\hline Costa Rica & 0 & 0 & 33.3 & 100 & 40.7 & 0 & 0 & 100 \\
\hline Dominica & 50 & 0 & 100 & 100 & 22.2 & 0 & 0 & 0 \\
\hline $\begin{array}{l}\text { Dominican } \\
\text { Republic }\end{array}$ & 100 & 100 & 33.3 & 100 & 37.0 & 100 & 100 & 100 \\
\hline Ecuador & 100 & 100 & 33.3 & 100 & 37.0 & 0 & 100 & 100 \\
\hline El Salvador & 50 & 100 & 66.7 & 100 & 38.9 & 100 & 100 & 100 \\
\hline Guatemala & 100 & 100 & 100 & 0 & 40.7 & 0 & 100 & 100 \\
\hline Guyana & 0 & 0 & 33.3 & 100 & 35.2 & 0 & 0 & 0 \\
\hline Grenada & 0 & 0 & 100 & 0 & 0 & 0 & 0 & 0 \\
\hline Haiti & 50 & 0 & 100 & 0 & 0 & 0 & 0 & 0 \\
\hline Honduras & 50 & 0 & 33.3 & 100 & 42.6 & 0 & 0 & 100 \\
\hline Jamaica & 50 & 0 & 100 & 100 & 42.6 & 0 & 0 & 0 \\
\hline Mexico & 100 & 0 & 33.3 & 100 & 42.6 & 0 & 100 & 100 \\
\hline Nicaragua & 100 & 100 & 66.7 & 100 & 72.2 & 0 & 0 & 100 \\
\hline Panama & 100 & 0 & 66.7 & 100 & 22.2 & 0 & 100 & 100 \\
\hline Paraguay & 0 & 0 & 0 & 0 & 0 & 0 & 0 & 0 \\
\hline Peru & 100 & 100 & 100 & 100 & 40.7 & 0 & 100 & 100 \\
\hline Puerto Rico & 50 & 0 & 100 & 100 & 7.4 & 0 & 0 & 0 \\
\hline St. Kitts and Nevis & 0 & 0 & 100 & 0 & 0 & 0 & 0 & 0 \\
\hline St. Lucia & 0 & 0 & 100 & 100 & 100 & 0 & 0 & 0 \\
\hline $\begin{array}{l}\text { St. Vincent and the } \\
\text { Grenadines }\end{array}$ & 0 & 0 & 100 & 0 & 0 & 0 & 0 & 0 \\
\hline Suriname & 50 & 100 & 66.7 & 0 & 0 & 100 & 100 & 100 \\
\hline $\begin{array}{l}\text { Trinidad and } \\
\text { Tobago }\end{array}$ & 0 & 0 & 33.3 & 100 & 96.3 & 0 & 0 & 0 \\
\hline Uruguay & 50 & 0 & 33.3 & 100 & 38.9 & 0 & 0 & 0 \\
\hline Venezuela, RB & 0 & 0 & 0 & 0 & 48.1 & 0 & 0 & 0 \\
\hline
\end{tabular}




\section{Step 4: Creation of the Composite Index}

Coming up with partial composite indicators reflecting jointly the various characterizations of a given reform dimension and their relative importance in the determination of the reform intensity is the most challenging part of the approach adopted in the paper. It requires two steps: (a) a multivariate analysis to check correlations between indicators and thus possible redundancy and (b) a principal component analysis followed by a factor analysis to compute the weighting factor for each indicator considering its redundancy (for details, see Freudenberg 2003). This weighting is needed to get to the aggregate single score. It is only for private sector participation that this procedure is not needed since we only had a single indicator for that reform dimension. Conceptually, this is reasonably straightforward. In practice, it is quite demanding in terms of data processing and quite a careful interpretation of the many partial results produced in the implementation of the two steps. To make this as clear as possible, it may be useful to go through an example.

\section{Illustration of the approach}

To illustrate the approach, we focus on the operational organization dimension. We collected information on three dimensions: the characterization of the transmission system operator, independent system operator, and wholesale market operator functions. The information was recorded as binary variable: either the country had adopted the reform or not. As a result, the normalization of the qualitative information transformed the information into 2 possible values: 0 or 100 for each of the three characteristics.

In the next step, we compute the (Pearson) correlations between the normalized values of these three characteristics to produce indicators within the operational organization dimension. These correlations are reported in Table 3. They can be interpreted as follows. When the correlation between two dimensions is low, it is unlikely that they share common determining factors. When they are statistically significantly correlated, there should be a presumption that a relatively large number of common parameters are likely to influence their values. We report these correlations at the three levels of significance typically relied upon in policy assessments (1,5 and 10\%). All correlations are found to be significant, suggesting that it is reasonable to assume the three operational dimensions are likely to be influenced by the same factors.

\begin{tabular}{|l|c|c|c|}
\hline \multicolumn{3}{|c|}{ Table 3: Correlation matrix of Operational Organization } \\
\hline Type of operator & $\begin{array}{c}\text { Type of operator } \\
\text { Transmission system } \\
\text { operator }\end{array}$ & $\begin{array}{c}\text { Independent system } \\
\text { operator }\end{array}$ & $\begin{array}{c}\text { Wholesale market } \\
\text { operator }\end{array}$ \\
\hline Transmission system operator & 1 & & \\
\hline Independent system operator & $0.5^{* * *}$ & $0.8^{* * *}$ & 1 \\
\hline Wholesale market operator & $0.4^{* *}$ & & \\
\hline
\end{tabular}

Note: Pearson correlation matrix. Significance level: $*=10$ percent, $* *=5$ percent, $* * *=1$ percent.

The strong correlation between the three characteristic is not really surprising for this industry but it does not inform the analysts much on the way the weights that should be assigned to each of them in assessing what drives the intensity of reform adoption on this dimension measured by the composite indicator value. A common option is to assign equal weights to each characteristic 
(which is what Foster et al. (2017) do. This boils down to computing the mean of all indicators values. But grouping variables with a high degree of correlation could cause one or more of the performance characteristics to be overestimated. To avoid this risk of bias, we relied on weighting procedure based on a principal component/factor analysis (PCA) which reduces the overlapping information between two or more variables. It transforms the correlated indicators into a set of independent factors (principal components) while preserving the maximum proportion of the total variation in the dataset (Nardo et al. 2005).

Formally, the analysis takes $\mathrm{Q}$ variables $x_{1}, x_{2}, \ldots x_{q}$ and finds linear combination of them to produce components $Z_{1}, Z_{2}, \ldots Z_{Q}$ that are uncorrelated:

$$
\begin{gathered}
Z_{1}=a_{11} x_{1}+a_{12} x_{2}+\cdots+a_{1 Q} x_{Q} \\
Z_{2}=a_{21} x_{1}+a_{22} x_{2}+\cdots+a_{2 Q} x_{Q} \\
\cdots \\
Z_{Q}=a_{Q 1} x_{1}+a_{Q 2} x_{2}+\cdots+a_{Q Q} x_{Q}
\end{gathered}
$$

The weights $a_{i j}$ (also called factor loadings) of the principal components applied to the variables $x_{j}$ are chosen so that the principal components $Z_{i}$ satisfy three conditions:

(i) They are uncorrelated/orthogonal.

(ii) The first supports the maximum proportion of the variance, the second supports the maximum of the remaining variance, and so on, until the last of the principal components absorbs all of the remaining variance not accounted by the preceding components.

(iii) $a_{i 1}^{2}+a_{i 2}^{2}+\cdots+a_{i Q}^{2}=1, i=1,2, \ldots Q$ (Nardo et al. 2005).

The eigenvalues of the indicators' correlation matrix are the variances of the principal components. They provide information on the variability in the data.

The decision on how many principal components should be retained in the analysis without losing too much information depends on the criteria ("stopping rules") selected. A criteria commonly used to select and determine the number of components consists of (a) having associated eigenvalues larger than 1, (b) individually contributing more than 10 percent to the explanation of overall variance, and (c) cumulatively contributing more than 80 percent to the explanation of the overall variance (Nardo et al. 2005).

The results of the PCA of the operational organization dimension are summarized in Table 4. Based on the condition just described, only the first two factors are retained. The PCA is conducted with the R software package FactoMineR.

\begin{tabular}{|l|c|c|c|}
\hline \multicolumn{3}{|c|}{ Table 4: Principal component analysis of Operational Organization } \\
\hline & \multicolumn{3}{|c|}{ Principal component } \\
\hline Variable & 1 & 2 & 3 \\
\hline Variance & 2.2 & 0.6 & 0.2 \\
\hline Percent of variance explained & 72.0 & 21.2 & 6.8 \\
\hline Cumulative percent of variance explained & 72.0 & 93.2 & 100.0 \\
\hline
\end{tabular}


The first two principal components reported in Table 5 are used as factors for the factor analysis. The factor loadings are then rotated through the Varimax methods to minimize the number of variables with high loadings on each factor (Nardo et al. 2005). Doing so simplifies the structure of the factors and makes their interpretation easier.

\begin{tabular}{|l|c|c|}
\hline \multicolumn{2}{|c|}{ Table 5: Factor loadings of indicators of Operational Organization } \\
\hline & 1 & 2 \\
\hline Indicator & 0.2 & 1.0 \\
\hline Transmission system operator & 0.9 & 0.3 \\
\hline Independent system operator & 0.9 & 0.2 \\
\hline Wholesale market operator & & \\
\hline
\end{tabular}

Extraction method: principal components, Varimax rotation

Note:

The last step involves constructing the weighting coefficients for the rotated factors loadings matrix. To do so, we rely on the method suggested by Nicoletti, Scarpetta, and Boyland (2000), in which each factor loading is squared, the factors with the highest value are selected, and the values are divided by the sum of the largest factor loadings. The weighting coefficients for each indicator reported in Table 6 are the outcome of this procedure. Based on these results, the composite index of operational organization can be reduced as follows:

Operational Organization index $=$

0.4 Transmission system operator + 0.3 Independent system operator +

0.3 Wholesale market operator

(4)

\begin{tabular}{|l|c|}
\hline Table 6: Weights for indicators of Operational Organization \\
\hline Indicator & Weight \\
\hline Transmission system operator & 0.4 \\
\hline Independent system operator & 0.3 \\
\hline Wholesale market operator & 0.3 \\
\hline
\end{tabular}

We rely on the same methodology to create partial composite indicators for Market structure and Regulatory autonomy and experience. The results are reported in the appendixes. The full set of partial composite indicators is then used to produce a single indicator from these four dimensions for each country. They are the basis for the following discussion of the spread of reforms in the region and of their association with expected policy outcomes.

\section{How widespread has reform adoption really been?}

Latin America has often been credited with a world leader in reforming its electricity sector, a perception possibly anchored in the high mediatic and academic profile of early reform decisions by Argentina. Table 8 provides a more precise sense of the spread of reforms in the region based on the computation of the total and partial reform scores for each country as well as the average scores and the standard deviation for each category for the region. The unbundling of the aggregate score makes it easier to have a more transparent perspective on the relative contribution of each group of partial reform categories. 
The average aggregate figure (51.3\%) indicates that many countries have not followed the reform wave in full. The most popular reform was the opening to private capital of at least part of the industry, with an average score of $71.7 \%$ while the least widespread reform is the change in the operational organization of the sector, with an average score of $34.7 \%$. The standard deviations around the mean are similar for all reforms.

The ability to attract at least some form of private participation in at least one of the business segments of the sector in over $90 \%$ of the countries of the region explains why this specific reform dimension may have been the most successful one apparently. But unfortunately, this indicator does not say much about the absolute and the relative size of the private sector contribution to the financing and/or operation of the sector. At the other extreme, the low scores for some of the reform options reflect the fact that many countries have not yet implemented any of the possible organizational changes or adopted more competitive market structures along the various possible dimensions. More than a third of the countries scored 0 on market structure, about a quarter had not created a separate regulatory agency, and almost half had not restructured the operational side of the sector (that is, they had no separate transmission system operator, independent system operator, or wholesale market operator).

\begin{tabular}{|c|c|c|c|c|c|}
\hline & \multirow{3}{*}{$\begin{array}{c}\text { Final aggregate } \\
\text { score }\end{array}$} & \multicolumn{4}{|c|}{ Partial reform dimension specific scores } \\
\hline & & Market structure & $\begin{array}{l}\text { Private sector } \\
\text { participation }\end{array}$ & $\begin{array}{c}\text { Regulatory autonomy } \\
\text { and experience }\end{array}$ & $\begin{array}{c}\text { Operational } \\
\text { organization }\end{array}$ \\
\hline Economy & & 0.23 & 0.27 & 0.26 & 0.24 \\
\hline Antigua and Barbuda & 19.8 & 0 & 33.3 & 41.7 & 0 \\
\hline Argentina & 78.7 & 75.0 & 100 & 74.1 & 63.6 \\
\hline Bahamas, The & 41.9 & 0 & 100 & 58.4 & 0 \\
\hline Barbados & 52.1 & 0 & 100 & 65.8 & 34.2 \\
\hline Belize & 55.9 & 50.0 & 100 & 67.6 & 0 \\
\hline Bolivia & 87.0 & 75.0 & 100 & 72.2 & 100 \\
\hline Brazil & 92.2 & 100 & 100 & 70.4 & 100 \\
\hline Chile & 82.1 & 75.0 & 100 & 87.1 & 63.6 \\
\hline Colombia & 78.7 & 75.0 & 100 & 74.1 & 63.6 \\
\hline Costa Rica & 35.5 & 0 & 33.3 & 70.4 & 34.2 \\
\hline Dominica & 48.4 & 25.0 & 100 & 61.1 & 0 \\
\hline Dominican Republic & 74.0 & 100 & 33.3 & 68.5 & 100.0 \\
\hline Ecuador & 65.2 & 100 & 33.3 & 68.5 & 63.6 \\
\hline El Salvador & 77.4 & 75.0 & 66.7 & 69.5 & 100 \\
\hline Guatemala & 70.4 & 100 & 100 & 20.4 & 63.6 \\
\hline Guyana & 26.6 & 0 & 33.3 & 67.6 & 0 \\
\hline Grenada & 26.7 & 0 & 100 & 0 & 0 \\
\hline Haiti & 32.5 & 25.0 & 100 & 0 & 0 \\
\hline Honduras & 41.5 & 25.0 & 33.3 & 71.3 & 34.2 \\
\hline Jamaica & 51.1 & 25.0 & 100 & 71.3 & 0 \\
\hline Mexico & 54.4 & 50.0 & 33.3 & 71.3 & 63.6 \\
\hline Nicaragua & 71.6 & 100 & 66.7 & 86.1 & 34.2 \\
\hline Panama & 60.6 & 50.0 & 66.7 & 61.1 & 63.6 \\
\hline Paraguay & 0 & 0 & 0 & 0 & 0 \\
\hline Peru & 83.5 & 100 & 100 & 70.4 & 63.6 \\
\hline Puerto Rico & 46.5 & 25.0 & 100 & 53.7 & 0 \\
\hline St. Kitts and Nevis & 26.7 & 0 & 100 & 0 & 0 \\
\hline St. Lucia & 52.8 & 0 & 100 & 100.0 & 0 \\
\hline $\begin{array}{l}\text { St. Vincent and the } \\
\text { Grenadines }\end{array}$ & 26.7 & 0 & 100 & 0 & 0 \\
\hline Suriname & 59.2 & 75.0 & 66.7 & 0 & 100 \\
\hline Trinidad and Tobago & 34.6 & 0 & 33.3 & 98.2 & 0 \\
\hline Uruguay & 32.8 & 25.0 & 33.3 & 69.5 & 0 \\
\hline Venezuela, RB & 6.3 & 0 & 0 & 24.1 & 0 \\
\hline Average & 51.3 & 40.9 & 71.7 & 55.0 & 34.7 \\
\hline Standard deviation & 0.24 & 0.39 & 0.34 & 0.31 & 0.38 \\
\hline Maximum value & 92.2 & 100 & 100 & 100 & 100 \\
\hline Minimum value & 0 & 0 & 0 & 0 & 0 \\
\hline
\end{tabular}

From a country specific benchmarking exercise perspective, it may useful to point out that the aggregate scores reveal Paraguay as an outlier. This is because it did not implement any of the 
reforms assessed in this diagnostic. At the other extreme, for the set of indicators available, Brazil performed best, with a score of $92 \%$, followed by Bolivia, Peru and Chile, all of which scored above 80 percent. It is also worth noting that six of the thirteen Caribbean countries analyzed are found in the last 10 countries of the ranking. This points to a significant lag with respect to the other countries in the region. It is also consistent with the more general observation on the relevance of the size of the country to the decision to reform along the lines typically suggested by policy advisers in the sectors, as noted by Foster et al. (2017). Some differences in policy and political preferences are unrelated to size, however but are also picked up by the scores as is the case for Venezuela for instance.

The unbundling of the reforms is useful as well to get a sense of the extent to which the various partial reforms are correlated in the region. This correlation is assessed across dimensions and within dimensions for the three dimensions anchored in multiple indicators. The results for the analysis of the simple correlation across the 4 main groups of reform dimensions are reported in Table 8.

From a policy perspective, the statistically insignificant correlations are just as interesting as the significant ones. The most significant correlation is between Market structure and Operational organization. It is probably explained by the fact that it is likely to be easier to introduce competition in the market if the operation of electricity system is unbundled. ${ }^{5}$ The correlation is not only statistically significant, it is also quite high since it stands at 0.8 . But it is also the only significant one. None of the other correlations is statistically significant. However, if they had been significant, they would be quite low since the values range from 0 to 0.3 . The fact that private participation is uncorrelated with market structure, organization and regulatory autonomy is insightful in itself in this region in view of the dominating role of this reform option in the region. In concrete terms, this implies that access to private financing is not directly linked to the most common reforms in LAC. Notably, creating a separate regulator or unbundling do not appear to have been necessary nor sufficient conditions to be able to attract private financing.

\begin{tabular}{|l|c|c|c|c|}
\hline \multicolumn{5}{|c|}{ Table 8: Correlation matrix of dimensions of Electricity Reform } \\
\hline & \multicolumn{4}{c|}{ Dimension } \\
\hline Dimension & $\begin{array}{c}\text { Market } \\
\text { structure }\end{array}$ & $\begin{array}{c}\text { Private } \\
\text { sector } \\
\text { participation }\end{array}$ & $\begin{array}{c}\text { Regulary } \\
\text { autonomy and } \\
\text { experience }\end{array}$ & $\begin{array}{c}\text { Operational } \\
\text { organization }\end{array}$ \\
\hline Market structure & 1.0 & & & \\
\hline Private sector participation autonomy and & 0.2 & 1.0 & & \\
\hline $\begin{array}{l}\text { Regulatory } \\
\text { experience }\end{array}$ & 0.3 & 0.0 & 1.0 & 1.0 \\
\hline Operational organization & $0.8^{* * *}$ & 0.1 & 0.2 & \\
\hline
\end{tabular}

Note: Pearson correlation matrix. Significance level: $*=10$ percent, $* *=5$ percent, $* * *=1$ percent.

\footnotetext{
${ }^{5}$ This is supported by the significant positive correlation between the level of competition and the level of unbundling reported in Table A.1 in the appendix. Similarly, unbundling makes it easier to have a stand alone transmission system operator, an independent system operator or a wholesale market operator.
} 


\section{Are policy outcomes correlated with each other?}

The analysis of the degree of adoption of reforms is interesting in itself but from a policy perspective, the main insights to be gained is the extent to which this intensity can somehow be related to changes in the efficiency, equity and quality with which the electricity service is being provided. To investigate the question, we first need to produce comparable synthetic performance indicators reflecting the most common policy areas of interest. We focus on 4 performance outcomes:

- Access, as measured by the percentage of the population with access to electricity (World Bank 2016a)

- $\quad$ Technical quality, as measured by the annual duration and frequency of outages per customer, the reliability of supply and the transparency of the tariff index, and energy losses in distribution (World Bank 2018a)

- $\quad$ Process quality, as measured by the number of procedures for getting electricity, the number of days for getting electricity, mechanisms for monitoring outages, mechanisms for restoring outages, financial deterrents aimed at limiting outages, and communication of tariff changes (World Bank 2018a)

- Affordability, as measured by the cost of getting a connection to the formal provision of electricity as a percentage of per capita Gross National Income (World Bank 2018a). Thus, this paper takes a broad interpretation of affordability, one linked more directly with access and not with the expenditure required to cover a pre-defined level of electricity consumption.

Table 9 reports the latest value observed for each of these 11 indicators as of 2018. The table makes it easier for sector specialist to see the absolute performance observed in each country. It shows, from a social perspective for instance, that while access is not a significant issue in most countries of the region, it continues to be a challenge for some of the poorest countries in Central America and in the Caribbean. It also reveals the enormous difference of the average affordability of the service in the region. 


\begin{tabular}{|c|c|c|c|c|c|c|c|c|c|c|c|}
\hline \multirow{2}{*}{$\begin{array}{l}\text { Dimension } \\
\text { Economy }\end{array}$} & \multirow{2}{*}{$\frac{\text { Access }}{\begin{array}{c}\text { Percent of } \\
\text { population with } \\
\text { electricity } \\
\text { access }\end{array}}$} & \multicolumn{3}{|c|}{ Technical quality } & \multicolumn{6}{|c|}{ Process quality } & \multirow{2}{*}{$\begin{array}{c}\text { Affordability } \\
\begin{array}{c}\text { Cost of electricity } \\
\text { as percent of } G N I \\
\text { per capita }\end{array}\end{array}$} \\
\hline & & $\begin{array}{l}\text { Total duration and } \\
\text { frequency of } \\
\text { outages per } \\
\text { customer a year }\end{array}$ & $\begin{array}{c}\text { Reliability of } \\
\text { supply and } \\
\text { transparency of } \\
\text { tariff index }\end{array}$ & $\begin{array}{l}\text { Energy losses in } \\
\text { distribution and } \\
\text { transmission as a } \\
\text { percent of output }\end{array}$ & $\begin{array}{c}\text { Mechanisms } \\
\text { for monitoring } \\
\text { outages }\end{array}$ & $\begin{array}{c}\text { Mechanisms } \\
\text { for restoring } \\
\text { outages }\end{array}$ & $\begin{array}{l}\text { Financial } \\
\text { deterrents } \\
\text { almed at } \\
\text { limiting } \\
\text { outages } \\
\text { outages }\end{array}$ & $\begin{array}{l}\text { Communication of } \\
\text { tariff changes }\end{array}$ & $\begin{array}{l}\text { Procedures } \\
\text { to get } \\
\text { service }\end{array}$ & $\begin{array}{c}\text { Time to get } \\
\text { service }\end{array}$ & \\
\hline $\begin{array}{l}\text { Antigua } \\
\text { and } \\
\text { Barbuda }\end{array}$ & 97.3 & 1 & 5 & 24.0 & 1 & 1 & 1 & 1 & 4 & 42 & 115 \\
\hline Argentina & 100 & 0 & 5 & 16.0 & 1 & 1 & 1 & 1 & 6 & 92 & 24 \\
\hline Bahamas & 100 & 0 & 0 & 12.0 & 1 & 1 & 0 & 1 & 5 & 67 & 124 \\
\hline Barbados & 100 & 0 & 0 & 6.0 & 1 & 1 & 1 & 1 & 8 & 88 & 64 \\
\hline Belize & 92.2 & 0 & 4 & 12.0 & 1 & 1 & 0 & 1 & 5 & 66 & 318 \\
\hline Bolivia & 93.0 & 1 & 6 & 14.0 & 1 & 1 & 1 & 1 & 8 & 42 & 689 \\
\hline Brazil & 100 & $0.5^{\mathrm{a}}$ & 5.4 & 16.0 & 1 & 1 & 1 & 1 & 4 & 64 & 54 \\
\hline Chile & 100 & 2 & 6 & 9.0 & 1 & 1 & 1 & 0 & 5 & 43 & 68 \\
\hline Colombia & 99.0 & 1 & 6 & 20.0 & 1 & 1 & 1 & 1 & 5 & 106 & 542 \\
\hline Costa Rica & 100 & 3 & 8 & 10.0 & 1 & 1 & 1 & 1 & 5 & 45 & 168 \\
\hline Dominica & 100 & 3 & 7 & 8.2 & 1 & 1 & 0 & 1 & 5 & 61 & 466 \\
\hline $\begin{array}{l}\text { Dominican } \\
\text { Republic }\end{array}$ & 100 & 0 & 4 & 34.0 & 1 & 1 & 0 & 1 & 7 & 67 & 249 \\
\hline Ecuador & 99.9 & 2 & 7 & 19.0 & 1 & 1 & 1 & 1 & 7 & 74 & 636 \\
\hline EISalvador & 98.6 & 1 & 8 & 12.0 & 1 & 1 & 1 & 1 & 4 & 88 & 883 \\
\hline Guatemala & 92.3 & 1 & 4 & 7.7 & 1 & 1 & 0 & 1 & 5 & 38 & 188 \\
\hline Guyana & 91.8 & 2 & 7 & 14.0 & 1 & 1 & 1 & 1 & 5 & 44 & 551 \\
\hline Grenada & 84.2 & 0 & 4 & 33.0 & 1 & 0 & 1 & 1 & 8 & 82 & 442 \\
\hline Haiti & 38.7 & 0 & 0 & 56.0 & 0 & 0 & 0 & 1 & 4 & 60 & 3522 \\
\hline Honduras & 87.6 & 0 & 0 & 25.0 & 0 & 1 & 0 & 1 & 7 & 39 & 791 \\
\hline Jamaica & 98.2 & 2 & 7 & 24.0 & 1 & 1 & 1 & 1 & 7 & 95 & 237 \\
\hline Mexico & 100 & 3 & 7 & 17.0 & 1 & 1 & 0 & 1 & 6.8 & 100 & 314 \\
\hline Nicaragua & 81.8 & 0 & 4 & 32.0 & 1 & 1 & 0 & 1 & 6 & 55 & 856 \\
\hline Panama & 93.4 & 3 & 8 & 13.0 & 1 & 1 & 1 & 1 & 5 & 35 & 17 \\
\hline Paraguay & 98.4 & 0 & 2 & 32.0 & 0 & 1 & 0 & 1 & 5 & 67 & 162 \\
\hline Peru & 94.8 & 1 & 6 & 7.0 & 1 & 1 & 1 & 1 & 5 & 67 & 350 \\
\hline Puerto Rico & 100 & 1 & 4 & 13.8 & 1 & 1 & 0 & 1 & 5 & 32 & 228 \\
\hline $\begin{array}{l}\text { St. Kitts } \\
\text { and Nevis }\end{array}$ & 100 & 0 & 0 & 17.8 & 0 & 0 & 0 & 0 & 4 & 18 & 239 \\
\hline St. Lucia & 97.8 & 3 & 7 & 9.3 & 1 & 1 & 0 & 1 & 6 & 26 & 83 \\
\hline $\begin{array}{l}\text { St. Vincent } \\
\text { and the } \\
\text { Grenadines }\end{array}$ & 100 & 0 & 0 & 7.4 & 1 & 0 & 0 & 1 & 3 & 52 & 52 \\
\hline Suriname & 87.2 & 0 & 0 & 8.0 & 1 & 1 & 0 & 1 & 4 & 113 & 634 \\
\hline $\begin{array}{l}\text { Trinidad } \\
\text { and Tobago }\end{array}$ & 100 & 1 & 6 & 6.0 & 1 & 1 & 1 & 1 & 4 & 61 & 212 \\
\hline Uruguay & 100 & 1 & 6 & 19.0 & 1 & 1 & 1 & 1 & 5 & 48 & 11 \\
\hline $\begin{array}{l}\text { Venezuela, } \\
\text { RB }\end{array}$ & 99.6 & 0 & 0 & 32.0 & 0 & 0 & 0 & 0 & 6 & 208 & 16713 \\
\hline
\end{tabular}

To get a more precise sense of the diversity of performance, it is useful to normalize the raw data. We do this through the max-min procedure, except for indicators that are inversely proportional to quality. For those cases, we adapt the formula in order to link the indicator value positively with quality (an increase in the value will increase the quality character). Indicators inversely proportional to quality are adapted with the following equation:

$$
I^{\prime}{ }_{q c}=100 \text { percent }-\frac{x_{q c}-\min \left(x_{q}\right)}{\max \left(x_{q}\right)-\min \left(x_{q}\right)},
$$

where $I^{\prime}{ }_{q c}$ is the normalized indicator $q$ of type "less is better." We then create the aggregate indicators Technical quality and Process quality (Access and Affordability are characterized only by one indicator and therefore do not require a aggregate index) following the same methodology used to create the synthetic governance index (see appendix B). Table B1 in Appendix B provides the normalized values of the performance indicators. These values are then used to produce a composite outcome performance indicator for each of the four policy dimensions of interest. The results are reported in Table 10. 


\begin{tabular}{|c|c|c|c|c|}
\hline \multirow[b]{2}{*}{ Economy } & \multicolumn{4}{|c|}{ Dimension } \\
\hline & Access & Technical quality & Process quality & Affordability \\
\hline Antigua and Barbuda & 95.6 & 64.3 & 93.2 & 99.4 \\
\hline Argentina & 100.0 & 80.4 & 79.4 & 99.9 \\
\hline Bahamas, The & 100.0 & 62.8 & 67.2 & 99.3 \\
\hline Barbados & 100.0 & 67.2 & 71.5 & 99.7 \\
\hline Belize & 87.3 & 79.2 & 67.3 & 98.2 \\
\hline Bolivia & 88.6 & 75.7 & 76.6 & 95.9 \\
\hline Brazil & 100.0 & 76.9 & 90.8 & 99.7 \\
\hline Chile & 100.0 & 69.1 & 72.5 & 99.7 \\
\hline Colombia & 98.4 & 71.3 & 82.0 & 96.8 \\
\hline Costa Rica & 100.0 & 66.3 & 88.7 & 99.1 \\
\hline Dominica & 100.0 & 63.5 & 67.8 & 97.3 \\
\hline Dominican Republic & 100.0 & 63.2 & 58.8 & 98.6 \\
\hline Ecuador & 99.8 & 65.9 & 77.2 & 96.3 \\
\hline El Salvador & 97.7 & 85.4 & 88.2 & 94.8 \\
\hline Guatemala & 87.4 & 72.1 & 70.3 & 98.9 \\
\hline Guyana & 86.6 & 69.6 & 88.8 & 96.8 \\
\hline Grenada & 74.2 & 63.9 & 60.0 & 97.4 \\
\hline Haiti & 0.0 & 30.8 & 49.3 & 79.0 \\
\hline Honduras & 79.8 & 53.3 & 51.3 & 95.3 \\
\hline Jamaica & 97.1 & 62.3 & 74.9 & 98.6 \\
\hline Mexico & 100.0 & 57.1 & 56.0 & 98.2 \\
\hline Nicaragua & 70.3 & 64.7 & 64.3 & 94.9 \\
\hline Panama & 89.2 & 64.1 & 89.8 & 100 \\
\hline Paraguay & 97.4 & 56.4 & 56.5 & 99.1 \\
\hline Peru & 91.5 & 80.8 & 86.3 & 98.0 \\
\hline Puerto Rico & 100.0 & 67.7 & 71.0 & 98.7 \\
\hline St. Kitts and Nevis & 100.0 & 58.6 & 37.5 & 98.6 \\
\hline St. Lucia & 96.4 & 62.7 & 67.5 & 99.6 \\
\hline St. Vincent and the Grenadines & 100.0 & 66.2 & 64.9 & 99.8 \\
\hline Suriname & 79.1 & 65.7 & 66.3 & 96.3 \\
\hline Trinidad and Tobago & 100.0 & 81.5 & 91.1 & 98.8 \\
\hline Uruguay & 100.0 & 72.1 & 88.4 & 100 \\
\hline Venezuela, RB & 99.3 & 48.2 & 8.3 & 0 \\
\hline Average & 91.4 & 66.3 & 70.4 & 94.6 \\
\hline Standard deviation & 0.18 & 0.10 & 0.18 & 0.17 \\
\hline Maximum value & 100 & 85.4 & 93.2 & 100 \\
\hline Minimum value & 0 & 30.8 & 8.3 & 0 \\
\hline
\end{tabular}

Table 10 shows that the intuition generated by the raw data is confirmed when the information is aggregated to provide a more encompassing perspective on each of these four dimensions. In absolute terms, the region does indeed perform well on average in terms of access and affordability, with average scores 91.4 percent and 94.6 percent, respectively. The same cannot be said for service and technical quality, where the averages are 70.4 percent and 66.3 percent, respectively. Moreover, there are many laggards in the region for which policy performance across indicators continues to be a problem (.e.g Haiti, for access and technical quality and the República Bolivariana de Venezuela for affordability and process quality.

To provide a fuller diagnostic of the performance outcomes, Table 11 reports the correlations across the four performance measures. The Pearson correlation is usually used to assess the linear relationship between two continuous variables. As we normalized all indicators, we are de facto relying on continuous variables. Pearson assumes that the variables are normally distributed and linear. To test the robustness of the policy insights, we also computed the Spearman correlation coefficient which accounts for the fact that the variables might tend to 
move in the same direction but not necessarily at a constant rate. The two correlation measures usually yield similar results unless the data are not normally distributed or significant nonlinearities characterize them in which case the Spearman coefficient is more insightful.

\begin{tabular}{|c|c|c|c|c|}
\hline \multicolumn{5}{|c|}{ Table 11: Correlation matrix of dimensions of performance } \\
\hline & \multicolumn{4}{|c|}{ Dimension } \\
\hline Measure & Access & Technical quality & Process quality & Affordability \\
\hline \multicolumn{5}{|l|}{ Pearson } \\
\hline Access & 1 & & & \\
\hline Technical quality & $0.6^{* * * *}$ & 1 & & \\
\hline Process quality & 0.2 & $0.7 * * *$ & 1 & \\
\hline Affordability & 0.1 & $0.4 * *$ & $0.7 * * *$ & 1 \\
\hline \multicolumn{5}{|l|}{ Spearman } \\
\hline Access & 1 & & & \\
\hline Technical quality & 0.1 & 1 & & \\
\hline Process quality & 0.2 & $0.7 * * *$ & 1 & \\
\hline Affordability & $0.5 * * *$ & 0.2 & $0.4 * *$ & 1 \\
\hline
\end{tabular}

The correlation analysis provides the following policy insights:

- Access and affordability are nonlinearly correlated with each other. This finding is not unexpected, given the complexity of tariff structures in many countries in the region and the widespread mistargeting of subsidies.

- Access and affordability are both positively and statistically significantly linearly correlated with technical quality. This finding suggests that the poor are likely to benefit from improved technical efficiency in the region.

- Affordability is positively correlated with process quality. This finding suggests that improvements in the way service caters to users are likely to have strong social payoffs.

- The strongest correlation is between the two quality dimensions. This finding, together with the social payoffs to quality improvements, points to the importance of measuring technical quality as rigorously as possible in the regulatory supervision of the sector.

\section{Were Reforms Correlated with Outcomes?}

The final step in the analysis of LAC's electricity governance reform experience is the assessment of the relationship between the reform indices and performance. In this case again, we compute their correlations using both the Pearson and Spearman measures. We do so for the synthetic governance index as well as for each of its main components.

The results of the Pearson and Spearman tests computed for the aggregate reform index are reported in Table 12. They lead to two main conclusions. First, there is no correlation between the aggregate reform index and access. In other words, on average, for the countries with a high access rate, the reforms have no statistically significant link with their good performance on access and for those starting with a low initial access rate, the reforms are unlikely to have made much of a difference to improve matters. Second, there is some credible correlation with technical quality and to a less robust extent to process quality. Indeed, the Pearson correlation shows a positive correlation with both technical and process quality while the Spearman 
correlation is significant only for technical quality. The difference may reflect the presence of outliers since the Pearson correlation is higher than the Spearman correlation and the Pearson is more sensitive to outliers.

\begin{tabular}{|l|c|c|}
\hline \multicolumn{2}{|c|}{ Table 12: Correlation between aggregate reform index and performance outcomes } \\
\hline & \multicolumn{2}{|c|}{ Reform aggregate index } \\
\hline Performance outcome & Pearson correlation & Spearman correlation \\
\hline Access & 0.1 & 0.0 \\
\hline Technical quality & $0.5^{* * *}$ & $0.5^{* * *}$ \\
\hline Process quality & $0.4^{* *}$ & 0.3 \\
\hline Affordability & $0.3^{*}$ & -0.1 \\
\hline
\end{tabular}

Figure 1 illustrates the much larger dispersion for the two quality measures compared with the access and affordability measures. The simple linear regressions confirm the earlier results on the stronger correlation between the governance and quality variables than between governance and access or affordability. The higher a country is on the governance scale, the more likely performance is to be positive.

Figure 1 Correlation between reform index and selected measures of performance in the electricity sector in Latin America and the Caribbean
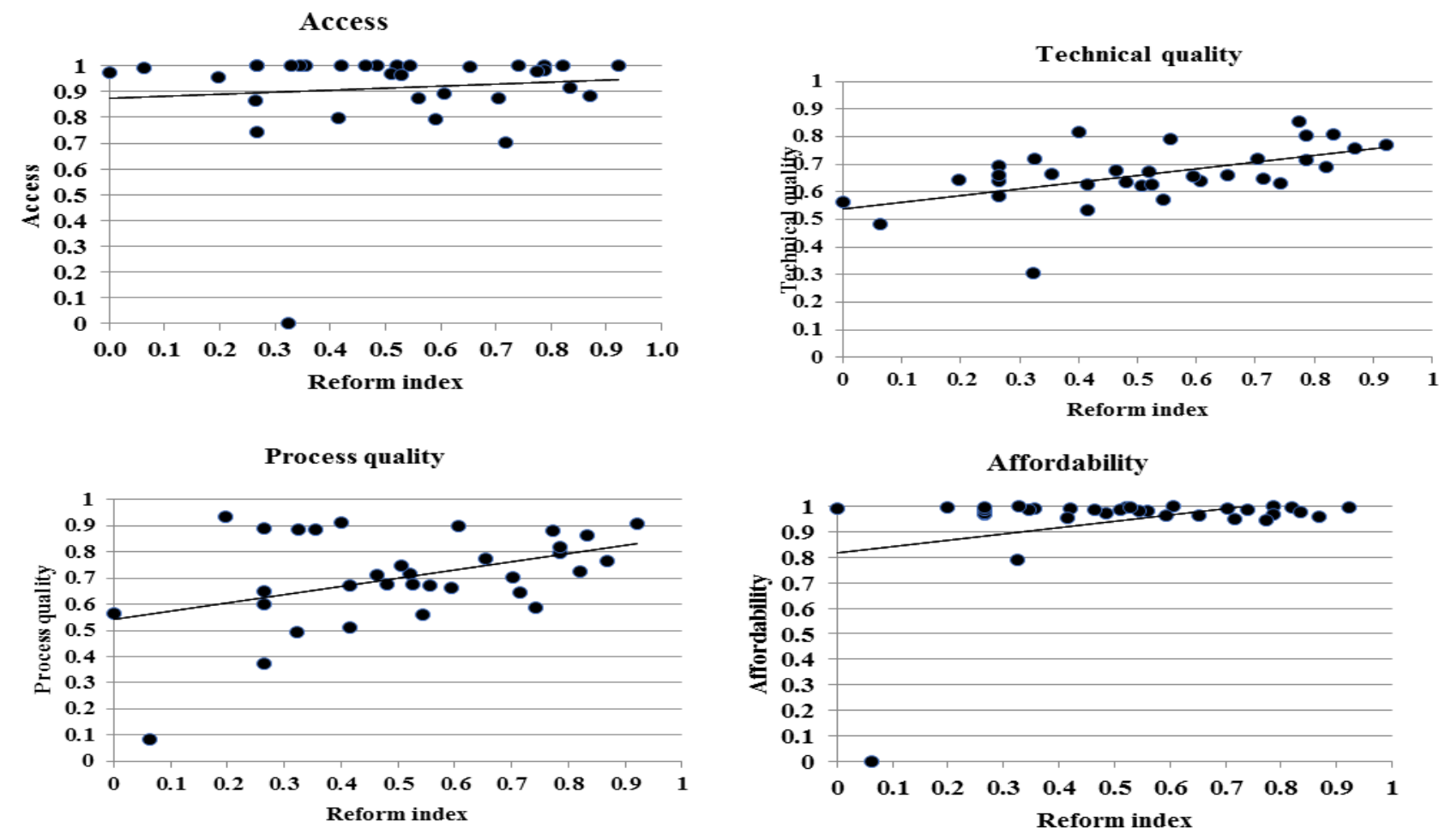

Table 13 provides the equivalent correlations between the various performance synthetic indicators and each of the partial reform dimensions. None of the partial reforms is correlated with all of the outcomes. Regulatory autonomy is the partial reform with the largest number of 
significant correlations with the various outcome performance indicators. It enjoys a statistically significant correlation at the $1 \%$ level with technical and process quality for both the Pearson and Spearman measure, although is it somewhat less significant for the Spearman one. It is also Pearson correlated to access but only at the 5\% significance level and this is not validated by the Spearman measure. Technical quality is the only outcome which seems to be correlated with almost all the partial reforms under both measures of correlation. The exception is private sector participation which is uncorrelated with almost all outcomes, except for a Pearson correlation with affordability at the 5\% significance level. But this is not validated by the Spearman measure..

\begin{tabular}{|c|c|c|c|c|}
\hline Measure of performance & & Dimens & electricity reform & \\
\hline Pearson & $\begin{array}{l}\text { Market } \\
\text { structure }\end{array}$ & $\begin{array}{l}\text { Private sector } \\
\text { participation }\end{array}$ & $\begin{array}{c}\text { Regulatory autonomy } \\
\text { and experience }\end{array}$ & $\begin{array}{l}\text { Operational } \\
\text { organization }\end{array}$ \\
\hline Access & 0.0 & -0.2 & $0.4 * *$ & 0.1 \\
\hline Technical quality & $0.4 * *$ & 0.2 & $0.5 * * *$ & $0.4 * *$ \\
\hline Process quality & 0.2 & 0.1 & $0.5 * * *$ & 0.3 \\
\hline Affordability & 0.2 & $0.4 * *$ & 0.2 & 0.2 \\
\hline \multicolumn{5}{|l|}{ Spearman } \\
\hline Access & -0.1 & 0.0 & 0.2 & 0.0 \\
\hline Technical quality & $0.4^{* *}$ & 0.2 & $0.4^{* *}$ & $0.4^{* *}$ \\
\hline Process quality & 0.1 & 0.0 & $0.4 * *$ & 0.2 \\
\hline Affordability & $-0.3^{*}$ & 0.1 & 0.0 & -0.1 \\
\hline
\end{tabular}

Note: Pearson correlation matrix. Significance level: $*=10$ percent, $* *=5$ percent, $* * *=1$ percent.

From a policy perspective, these results can be interpreted as follows. They reinforce a recurring message that private participation alone will not lead to significant improvements on most dimensions and that the development of an autonomous regulatory capacity is essential. They also show suggest that it is important to think of reforms as packages which clear interactions. However, it is easy to overestimate the impact of some these interactions as suggested by the lack of correlation between the creation of separate regulatory capacity and the restructuring of the market structure and organization.

\section{Conclusion}

The analysis confirms earlier results reached ten and five years ago by Andres et al. (2008); Andres et al. (2013); and Balza et al. (2013) suggesting that reforms have been effective at influencing the supply side of the sector in general. However, it also confirms that they have not been as effective as dealing with the demand side as indicated by the disappointing correlation with access and affordability. An update of the earlier results shows no significant change to the earlier diagnostics. This implies that unless the next wave of reforms accounts more explicitly for the undelivered social promises of the first wave reforms A business as usual governance strategy is unlikely to do any better.

The results are rigorous and precise enough to make the concerns identified credible and robust enough. In addition to confirmation of earlier results, they show that not all forms of governance reforms matter as much as sometimes argued. Notably, they show that the correlations across dimensions and within dimensions are easily mis-estimated, when they are not simply ignored. 
Getting the governance of the supply side right will not necessarily address the social concerns and strengthening regulatory governance will not necessarily interfere with the supply side, yet provide more margin to address demand side concerns.

A subtler policy extrapolation of the correlation analysis is that reforms may need to be better targeted to the specific constraints and opportunities observed in each country. A given reform may have different results in different countries. In other words, one size does not fit all. More specifically, the reforms most likely to reach the desired policy goals are those designed to deal most explicitly with the institutional weaknesses and limitations of a particular country (for a survey, see Estache 2018).

Additional work should also account more explicitly for the growing role of less formal institutions in the sector, which have been effective at mitigating some of the weaknesses of formal actors. The region has benefited from an increased role for consumer associations, cooperatives, nongovernmental organizations, and other civil society actors. Any of these actors could have made a difference in the social outcomes observed. Many are likely to be able to have an impact in the implementation and monitoring of the new wave of reforms, including those aiming at greening the sector. Learning more about these institutions should be part of future assessments of the governance of the sector and of reform options. 


\section{References}

Andres, L., J.L. Guasch, and S.L. Azumendi. 2008. Regulatory Governance and Sector Performance: Methodology and Evaluation for Electricity Distribution in Latin America. Policy Research Working Paper 4494, World Bank, Washington, DC.

Andres, L., J. Schwartz, and J. Luis Guasch. 2013. Uncovering the Drivers of Utility Performance: Lessons from Latin America and the Caribbean on the Role of the Private Sector, Regulation, and Governance in the Power, Water, and Telecommunication Sectors. World Bank, Washington, DC.

Balza, L., R. Jimenez, and J. Mercado. 2013. Privatization, Institutional Reform, and Performance in the Latin American Electricity Sector. Inter-American Development Bank, Washington, DC.

Bensch, G, M. Sievert, J. Langbein, and N. Kneppel. 2016. Effects and Mechanisms of MarketBased Reforms on Access to Electricity in Developing Countries: A Systematic Review. 3ie Systematic Review 31. London: International Initiative for Impact Evaluation (3ie).

Estache, A. 2018. "Institutions for Infrastructure in Developing Countries: What We Know and the Lot We still Need to Know." In Frontiers in Development Economics, ed. F. Bourguignon, ECARES Working Paper 2016-27. Princeton, NJ: Princeton University Press.

Foster, V., S. Witte, S.G. Banerjee, and A. Moreno. 2017. Charting the Diffusion of Power Sector Reforms across the Developing World. Policy Research Working Paper 8235. World Bank, Energy and Extractives Global Practice Group, Washington, DC. http://documents.worldbank.org/curated/en/576801510076208252/pdf/WPS8235.pdf.

Freudenberg, M. 2003. Composite Indicators of Country Performance: A Critical Assessment. OECD Science, Technology and Industry Working Paper 16, Organisation for Economic Co-operation and Development, Paris. https://doi.org/10.1787/405566708255. [Barbara: You've changed the editing style of working papers.]

Jamasb, T., R. Nepal, and G.R. Timilsina. 2017. "A Quarter Century Effort Yet to Come of Age: A Survey of Electricity Sector Reform in Developing Countries." Energy Journal 38 (3): 195-234. DOI: DOI: 10.5547/01956574.38.3.tjam.

Nardo, M. M. Saisana, A. Saltelli and S. Tarantola, A. Hoffman, and E. Giovannini. 2005. Handbook on Constructing Composite Indicators: Methodology and User Guide. Paris: Organisation for Economic Co-operation and Development. http://www.oecd.org/sdd/42495745.pdf.

Nicoletti, G., S. Scarpetta, and O. Boyland. 2000. Summary Indicators of Product Market Regulation with an Extension to Employment Protection Legislation. OECD Economic Department Working Paper 226, Organisation for Economic Co-operation and Development, Paris. https://doi.org/10.2139/ssrn.201668

Polemis, M.L. 2016. New Evidence on the Impact of Structural Reforms on Electricity Sector Performance. Energy Policy 92: 420-31.

World Bank. 2016. Access to Electricity (\% of Population). https://data.worldbank.org/indicator/EG.ELC.ACCS.ZS.

—. 2018a. Doing Business: Getting Electricity. Washington, DC.

http://www.doingbusiness.org/data/exploretopics/getting-electricity

-2018b. Doing Business: Getting Electricity. Comparing Business Regulation

for Domestic Firms in 190 Economies. Washington, DC. 
http://www.doingbusiness.org/content/dam/doingBusiness/media/AnnualReports/English/DB2018-Full-Report.pdf.

for Domestic Firms in 190 Economies. Washington, DC.

http://www.doingbusiness.org/content/dam/doingBusiness/media/Annual-

Reports/English/DB2018-Full-Report.pdf 


\section{Appendix A: Aggregate Indicator of Electricity Reforms}

\begin{tabular}{|l|c|c|}
\hline \multicolumn{3}{|c|}{ Table A.1 Correlation matrix of Market Structure dimension } \\
\hline & \multicolumn{2}{|c|}{ Indicator } \\
\hline Indicator & Level of competition & Level of unbundling \\
\hline Level of competition & 1.0 & 1.0 \\
\hline Level of unbundling & $0.6^{* * *}$ & \\
\hline
\end{tabular}

Note: Pearson correlation matrix. Significance level: $*=10$ percent, $* *=5$ percent, $* * *=1$ percent.

\begin{tabular}{|l|c|c|}
\hline \multicolumn{3}{|c|}{ Table A.2 Principal component analysis of Market Structure dimension } \\
\hline & \multicolumn{2}{|c|}{ Principal component } \\
\hline Variable & 1 & 2 \\
\hline Variance & 1.6 & 0.4 \\
\hline Percent of variance explained & 81.2 & 18.8 \\
\hline Cumulative percent of variance explained & 81.2 & 100.0 \\
\hline
\end{tabular}

\begin{tabular}{|l|c|}
\hline \multicolumn{2}{|c|}{ Table A.3 Factor loadings of indicators of Market Structure dimension } \\
\hline Indicator & Factor \\
\hline Level of competition & 0.9 \\
\hline Level of unbundling & 0.9 \\
\hline \multicolumn{2}{|c|}{ Note: Extraction method: principal components, Varimax rotation. } \\
\hline
\end{tabular}

\begin{tabular}{|l|c|}
\hline \multicolumn{2}{|c|}{ Table A.4 Weights for indicators of Market Structure dimension } \\
\hline Indicator & Weight \\
\hline Level of competition & 0.5 \\
\hline Level of unbundling & 0.5 \\
\hline
\end{tabular}

\begin{tabular}{|l|c|c|}
\hline \multicolumn{2}{|c|}{ Table A.5 Correlation matrix of regulatory autonomy and experience dimension } \\
\hline & \multicolumn{2}{|c|}{ Indicator } \\
\hline Indicator & Separate energy regulator & Year of creation of regulator \\
\hline Separate energy regulator & 1.0 & 1.0 \\
\hline Year of creation of regulator & $0.4^{* *}$ & \\
\hline
\end{tabular}

Note: Pearson correlation matrix. Significance level: $*=10$ percent, $* *=5$ percent, $* * *=1$ percent.

\begin{tabular}{|l|c|c|}
\hline \multicolumn{2}{|c|}{$\begin{array}{c}\text { Table A.6 Principal component analysis of Regulatory autonomy and experience } \\
\text { dimension }\end{array}$} \\
\hline & 1 & \multicolumn{2}{c|}{ Principal component } \\
\hline Variable & 1.4 & 2 \\
\hline Variance & 71.0 & 0.6 \\
\hline Percent of variance explained & 71.0 & 29.0 \\
\hline Cumulative percent of variance explained & \multicolumn{2}{|c|}{100.0} \\
\hline
\end{tabular}




\begin{tabular}{|c|c|c|}
\hline \multicolumn{3}{|c|}{$\begin{array}{c}\text { Table A.7 Factor loadings of indicators of Regulatory autonomy and experience } \\
\text { dimension }\end{array}$} \\
\hline & \multicolumn{2}{|c|}{ Factor } \\
\hline Indicator & 1 & 2 \\
\hline Separate energy regulator & 0.8 & -0.5 \\
\hline Year of creation of regulator & 0.8 & 0.5 \\
\hline
\end{tabular}

Note: Extraction method: principal components, Varimax rotation.

\begin{tabular}{|l|c|}
\hline \multicolumn{2}{|c|}{ Table A.8 Weights for indicators of Regulatory autonomy and experience dimension } \\
\hline Indicator & Weight \\
\hline Separate energy regulator & 0.5 \\
\hline Year of creation of regulator & 0.5 \\
\hline
\end{tabular}

\begin{tabular}{|l|c|c|c|c|}
\hline \multicolumn{5}{|c|}{ Table A.9 Principal component analysis of aggregate index of Electricity Reforms } \\
\hline & \multicolumn{5}{|c|}{ Principal component } \\
\hline Variable & 1 & 2 & 3 & 4 \\
\hline Variance & 2.0 & 1.0 & 0.8 & 0.2 \\
\hline Percent of variance explained & 49.5 & 25.2 & 21.0 & 4.3 \\
\hline Cumulative percent of variance explained & 49.5 & 74.7 & 95.7 & 100.0 \\
\hline
\end{tabular}

\begin{tabular}{|l|c|c|c|}
\hline \multicolumn{3}{|c|}{ Table A.10 Factor loadings of dimensions of aggregate index of Electricity Reforms } \\
\hline \multicolumn{3}{|c|}{ Factor } \\
\hline Indicator & 1 & 2 & 3 \\
\hline Market structure & 0.9 & 0.1 & 0.2 \\
\hline Regulatory autonomy and experience & 0.1 & 0.0 & 1.0 \\
\hline Operational organization & 1.0 & 0.0 & 0.1 \\
\hline Private sector participation & 0.1 & 1.0 & 0.0 \\
\hline
\end{tabular}

Note: Extraction method: principal components, Varimax rotation.

\begin{tabular}{|l|c|}
\hline \multicolumn{2}{|c|}{ Table A.11 Weights of dimensions of aggregate index of Electricity Reforms } \\
\hline Dimension & Weight \\
\hline Market structure & 0.2 \\
\hline Regulatory autonomy and experience & 0.3 \\
\hline Operational organization & 0.2 \\
\hline Private sector participation & 0.3 \\
\hline
\end{tabular}




\section{Appendix B: Normalization of the raw performance indicators}

\begin{tabular}{|c|c|c|c|c|c|c|c|c|c|c|c|}
\hline \multirow{2}{*}{$\begin{array}{l}\text { Dimension } \\
\text { Economy }\end{array}$} & \multirow{2}{*}{$\begin{array}{c}\text { Access } \\
\text { Percent of } \\
\text { population } \\
\text { with } \\
\text { electricity } \\
\text { access }\end{array}$} & \multicolumn{3}{|c|}{ Technical quality } & \multicolumn{6}{|c|}{ Process quality } & \multirow{2}{*}{$\begin{array}{c}\text { Affordability } \\
\begin{array}{c}\text { Cost of electricity } \\
\text { as percent of GNI } \\
\text { per capita }\end{array}\end{array}$} \\
\hline & & $\begin{array}{l}\text { Total duration } \\
\text { and frequency } \\
\text { of outages per } \\
\text { customer a year }\end{array}$ & $\begin{array}{l}\text { Reliability of } \\
\text { supply and } \\
\text { transparency } \\
\text { of tariff index }\end{array}$ & $\begin{array}{l}\text { Energy losses in } \\
\text { distribution and } \\
\text { transmission as a } \\
\text { percent of output }\end{array}$ & $\begin{array}{c}\text { Mechanisms } \\
\text { for monitoring } \\
\text { outages }\end{array}$ & $\begin{array}{l}\text { Mechanis } \\
\text { ms for } \\
\text { restoring } \\
\text { outages }\end{array}$ & $\begin{array}{c}\text { Financial } \\
\text { deterrents } \\
\text { aimed at } \\
\text { limiting } \\
\text { outages }\end{array}$ & $\begin{array}{l}\text { Communication } \\
\text { of tariff changes }\end{array}$ & $\begin{array}{l}\text { Procedures } \\
\text { to get } \\
\text { service }\end{array}$ & $\begin{array}{c}\text { Time to get } \\
\text { service }\end{array}$ & \\
\hline $\begin{array}{l}\text { Antigua and } \\
\text { Barbuda }\end{array}$ & 95.6 & 66.7 & 62.5 & 64.0 & 100 & 100 & 100 & 100 & 80 & 87.4 & 99.4 \\
\hline Argentina & 100 & 100 & 62.5 & 80.0 & 100 & 100 & 100 & 100 & 40 & 61.1 & 99.9 \\
\hline Bahamas & 100 & 100 & 0 & 88.0 & 100 & 100 & 0 & 100 & 60 & 74.2 & 99.3 \\
\hline Barbados & 100 & 100 & 0 & 100 & 100 & 100 & 100 & 100 & 0 & 63.2 & 99.7 \\
\hline Belize & 87.3 & 100 & 50.0 & 88.0 & 100 & 100 & 0 & 100 & 60 & 74.7 & 98.2 \\
\hline Bolivia & 88.6 & 66.7 & 75.0 & 84.0 & 100 & 100 & 100 & 100 & 0 & 87.4 & 95.9 \\
\hline Brazil & 100 & 83.3 & 67.5 & 80.0 & 100 & 100 & 100 & 100 & 80 & 75.7 & 99.7 \\
\hline Chile & 100 & 33.3 & 75.0 & 94.0 & 100 & 100 & 100 & 0 & 60 & 86.8 & 99.7 \\
\hline Colombia & 98.4 & 66.7 & 75.0 & 72.0 & 100 & 100 & 100 & 100 & 60 & 53.7 & 96.8 \\
\hline Costa Rica & 100 & 0 & 100 & 92.0 & 100 & 100 & 100 & 100 & 60 & 85.8 & 99.1 \\
\hline Dominica & 100 & 0 & 87.5 & 95.6 & 100 & 100 & 0 & 100 & 60 & 77.4 & 97.3 \\
\hline $\begin{array}{l}\text { Dominican } \\
\text { Rep. }\end{array}$ & 100 & 100 & 50.0 & 44.0 & 100 & 100 & 0 & 100 & 20 & 74.2 & 98.6 \\
\hline Ecuador & 99.8 & 33.3 & 87.5 & 74.0 & 100 & 100 & 100 & 100 & 20 & 70.5 & 96.3 \\
\hline El Salvador & 97.7 & 66.7 & 100 & 88.0 & 100 & 100 & 100 & 100 & 80 & 63.2 & 94.8 \\
\hline Guatemala & 87.4 & 66.7 & 50.0 & 96.6 & 100 & 100 & 0 & 100 & 60 & 89.5 & 98.9 \\
\hline Guyana & 86.6 & 33.3 & 87.5 & 84.0 & 100 & 100 & 100 & 100 & 60 & 86.3 & 96.8 \\
\hline Grenada & 74.2 & 100 & 50.0 & 46.0 & 100 & 0 & 100 & 100 & 0 & 66.3 & 97.4 \\
\hline Haiti & 0 & 100 & 0 & 0 & 0 & 0 & 0 & 100 & 80 & 77.9 & 79.0 \\
\hline Honduras & 79.8 & 100 & 0 & 62.0 & 0 & 100 & 0 & 100 & 20 & 88.9 & 95.3 \\
\hline Jamaica & 97.1 & 33.3 & 87.5 & 64.0 & 100 & 100 & 100 & 100 & 20 & 59.5 & 98.6 \\
\hline Mexico & 100 & 0 & 87.5 & 78.0 & 100 & 100 & 0 & 100 & 24 & 56.6 & 98.2 \\
\hline Nicaragua & 70.3 & 100 & 50.0 & 48.0 & 100 & 100 & 0 & 100 & 40 & 80.5 & 94.9 \\
\hline Panama & 89.2 & 0 & 100 & 86.0 & 100 & 100 & 100 & 100 & 60 & 91.1 & 100 \\
\hline Paraguay & 97.4 & 100 & 25.0 & 48.0 & 0 & 100 & 0 & 100 & 60 & 74.2 & 99.1 \\
\hline Peru & 91.5 & 66.7 & 75.0 & 98.0 & 100 & 100 & 100 & 100 & 60 & 74.2 & 98.0 \\
\hline Puerto Rico & 100 & 66.7 & 50.0 & 84.4 & 100 & 100 & 0 & 100 & 60 & 92.6 & 98.7 \\
\hline $\begin{array}{l}\text { St. Kitts and } \\
\text { Nevis }\end{array}$ & 100 & 100 & 0 & 76.4 & 0 & 0 & 0 & 0 & 80 & 100 & 98.6 \\
\hline St. Lucia & 96.4 & 0 & 87.5 & 93.4 & 100 & 100 & 0 & 100 & 40 & 95.8 & 99.6 \\
\hline $\begin{array}{l}\text { St. Vincent } \\
\text { and the } \\
\text { Grenadines }\end{array}$ & 100 & 100 & 0 & 97.2 & 100 & 0 & 0 & 100 & 100 & 82.1 & 99.8 \\
\hline Suriname & 79.1 & 100 & 0 & 96.0 & 100 & 100 & 0 & 100 & 80 & 50.0 & 96.3 \\
\hline $\begin{array}{l}\text { Trinidad and } \\
\text { Tobago }\end{array}$ & 100 & 66.7 & 75.0 & 100 & 100 & 100 & 100 & 100 & 80 & 77.4 & 98.8 \\
\hline Uruguay & 100 & 66.7 & 75.0 & 74.0 & 100 & 100 & 100 & 100 & 60 & 84.2 & 100 \\
\hline $\begin{array}{l}\text { Venezuela, } \\
\text { RB }\end{array}$ & 99.3 & 100 & 0 & 48.0 & 0 & 0 & 0 & 0 & 40 & 0 & 0 \\
\hline
\end{tabular}




\section{Appendix C Aggregate Performance Indicators}

\begin{tabular}{|l|c|c|c|}
\hline \multicolumn{3}{|c|}{ Table C.1 Correlation matrix of Technical Quality dimension } \\
\hline & \multicolumn{2}{|c|}{ Indicator } \\
\hline $\begin{array}{l}\text { Indicator } \\
\text { Total duration and frequency of outages per } \\
\text { customer a year }\end{array}$ & $\begin{array}{c}\text { Total duration and } \\
\text { frequency of outages } \\
\text { per customer a year }\end{array}$ & $\begin{array}{c}\text { Reliability of supply } \\
\text { and transparency of } \\
\text { tariff index }\end{array}$ & $\begin{array}{c}\text { Energy losses in } \\
\text { distribution/ } \\
\text { transmission as a } \\
\text { percent of output }\end{array}$ \\
\hline $\begin{array}{l}\text { Reliability of supply and transparency of tariff } \\
\text { index }\end{array}$ & 1.0 & 1.0 & \\
\hline $\begin{array}{l}\text { Energy losses in distribution/transmission as a } \\
\text { percent of output }\end{array}$ & $-0.8 * * *$ & $0.3 *$ & \\
\hline
\end{tabular}

Note: Pearson correlation matrix. Significance level: $*=10$ percent, $* *=5$ percent, $* * *=1$ percent.

\begin{tabular}{|l|c|c|c|}
\hline \multicolumn{3}{|c|}{ Table C.2 Principal component analysis of Technical Quality dimension } \\
\hline & \multicolumn{3}{|c|}{ Principal component } \\
\hline Variable & 1 & 2 & 3 \\
\hline Variance & 2.0 & 0.8 & 0.2 \\
\hline Percent of variance explained & 66.7 & 26.1 & 7.2 \\
\hline Cumulative percent of variance explained & 66.7 & 92.8 & 100.0 \\
\hline
\end{tabular}

\begin{tabular}{|l|c|c|}
\hline \multicolumn{3}{|c|}{ Table C.3 Factor loadings of indicators of Technical Quality } \\
\hline \multicolumn{2}{|c|}{$R C$} \\
\hline Indicator & 1 & 2 \\
\hline Total duration and frequency of outages per customer a year & -0.9 & -0.2 \\
\hline Reliability of supply and transparency of tariff index & 0.9 & 0.1 \\
\hline Energy losses in distribution/transmission as a percent of output & 0.2 & 1.0 \\
\hline \multicolumn{2}{|c|}{ Note: Extraction method: principal components, Varimax rotation } \\
\hline
\end{tabular}

\begin{tabular}{|l|c|}
\hline \multicolumn{2}{|c|}{ Table C.4 Weights for indicators of Technical Quality } \\
\hline Indicator & Weight \\
\hline Total duration and frequency of outages per customer a year & 0.3 \\
\hline Reliability of supply and transparency of tariff index & 0.3 \\
\hline $\begin{array}{l}\text { Energy losses in distribution/transmission as a percent of } \\
\text { output }\end{array}$ & 0.4 \\
\hline
\end{tabular}




\begin{tabular}{|c|c|c|c|c|c|c|}
\hline \multicolumn{7}{|c|}{ Table C.5 Correlation matrix of Process Quality dimension } \\
\hline & \multicolumn{6}{|c|}{ Dimension } \\
\hline Dimension & $\begin{array}{c}\text { Mechanisms } \\
\text { for monitoring } \\
\text { outages }\end{array}$ & $\begin{array}{c}\text { Mechanisms } \\
\text { for restoring } \\
\text { outages }\end{array}$ & $\begin{array}{c}\text { Financial } \\
\text { deterrents } \\
\text { aimed at } \\
\text { limiting } \\
\text { outages }\end{array}$ & $\begin{array}{l}\text { Communication of } \\
\text { tariff changes }\end{array}$ & $\begin{array}{l}\text { Procedures } \\
\text { for getting } \\
\text { electricity }\end{array}$ & $\begin{array}{l}\text { Time for } \\
\text { getting } \\
\text { electricity }\end{array}$ \\
\hline $\begin{array}{l}\text { Mechanisms for monitoring } \\
\text { outages }\end{array}$ & 1.0 & & & & & \\
\hline $\begin{array}{l}\text { Mechanisms for restoring } \\
\text { outages }\end{array}$ & $0.5 * * *$ & 1.0 & & & & \\
\hline $\begin{array}{l}\text { Financial deterrents aimed at } \\
\text { limiting outages }\end{array}$ & $0.4 * *$ & 0.3 & 1.0 & & & \\
\hline $\begin{array}{l}\text { Communication of tariff } \\
\text { changes }\end{array}$ & $0.5^{* * *}$ & $0.5 * * *$ & 0.1 & 1.0 & & \\
\hline $\begin{array}{l}\text { Procedures for getting } \\
\text { electricity }\end{array}$ & -0.1 & -0.1 & -0.1 & -0.1 & 1.0 & \\
\hline Time for getting electricity & 0.2 & 0.2 & 0.0 & 0.2 & 0.2 & 1.0 \\
\hline
\end{tabular}

\begin{tabular}{|l|l|c|c|c|c|c|}
\hline \multicolumn{7}{|c|}{ Table C.6 Principal component analysis of Process Quality dimension } \\
\hline & & \multicolumn{7}{|c|}{ Principal component } \\
\hline Variable & 1 & 2 & 3 & 4 & 5 & 6 \\
\hline Variance & 2.3 & 1.2 & 0.9 & 0.7 & 0.5 & 0.4 \\
\hline Percent of variance explained & 37.7 & 20.6 & 15.0 & 11.6 & 8.6 & 6.6 \\
\hline Cumulative percent of variance explained & 37.7 & 58.2 & 73.2 & 84.8 & 93.4 & 100.0 \\
\hline
\end{tabular}

\begin{tabular}{|l|c|c|c|c|}
\hline \multicolumn{5}{|c|}{ Table C.7 Factor loadings of indicators of Process Quality dimension } \\
\hline \multicolumn{7}{|l|}{} & 1 & 2 & 3 & 4 \\
\hline Indicator & 0.7 & 0.5 & 0.1 & 0.0 \\
\hline Mechanisms for monitoring outages & 0.7 & 0.2 & -0.1 & 0.2 \\
\hline Mechanisms for restoring outages & 0.1 & 0.9 & -0.1 & 0.0 \\
\hline Financial deterrents aimed at limiting outages & 0.9 & -0.1 & 0.0 & 0.1 \\
\hline Communication of tariff changes & -0.1 & -0.1 & 1.0 & 0.1 \\
\hline Procedures for getting electricity & 0.1 & 0.0 & 0.1 & 1.0 \\
\hline Time for getting electricity Note: Extraction method: principal components, Varimax rotation. \\
\hline \multicolumn{5}{|l}{} \\
\hline
\end{tabular}

\begin{tabular}{|l|c|}
\hline \multicolumn{2}{|c|}{ Table C.8 Weights for indicators of Process Quality dimension } \\
\hline Indicator & Weight \\
\hline Mechanisms for monitoring outages & 0.1 \\
\hline Mechanisms for restoring outages & 0.1 \\
\hline Financial deterrents aimed at limiting outages & 0.2 \\
\hline Communication of tariff changes & 0.2 \\
\hline Procedures for getting electricity & 0.2 \\
\hline Time for getting electricity & 0.2 \\
\hline
\end{tabular}

